\title{
Fragmenty dwóch nieznanych druków z oficyny Jana Hallera (z 1506 i 1509 roku)*
}

Streszczenie. W komunikacie opisano odnalezione w Archiwum Archidiecezjalnym w Gnieźnie fragmenty dwóch nieznanych druków z oficyny Jana Hallera. Są to pozostałości dwóch egzemplarzy Ars Minor Aeliusa Donata (wydane 24 grudnia 1506) oraz drukowany formularz mandatu arcybiskupa Andrzeja Boryszewskiego (wydany ok. 12 marca 1509-przed 8 kwietnia 1509).

SŁowa Kluczowe: Jan Haller, Donatus, Ars Minor, Andrzej Boryszewski, starodruki, typografia, Archiwum Archidiecezjalne w Gnieźnie.

W niniejszym komunikacie opiszę fragmenty dwóch druków z oficyny Jana Hallera odnalezionych w Archiwum Archidiecezjalnym w Gnieźnie. Sa to pozycje nieznane polskim bibliografiom oraz opracowaniom poświęconym tej drukarni ${ }^{1}$.

* Tekst powstał w ramach realizacji grantu „Inwentaryzacja zasobu Biblioteki Katedralnej w Gnieźnie", finansowanego z Narodowego Programu rozwoju Humanistyki MNiSW (nr 11H 120179 81), kierownik dr Piotr Pokora.

${ }^{1}$ A. Kawecka-Gryczowa, Jan Haller, w: Drukarze dawnej Polski od XV do XVIII wieku, t. 1: Małopolska, cz. 1: wiek XV-XVI, red. A. Kawecka-Gryczowa, Wrocław 1982, s. 44-62; H. Bułhak, Varia Hallerowskie, "Roczniki Biblioteczne” 1985, t. 29, z. 1-2, s. 23-31; idem, Miscellanea Bibliographica. Druki krakowskie XVI w. Jan Haller, „Biuletyn Biblioteki Jagiellońskiej” 1991, t. 41, s. 73-80; idem, Miscellanea bibliographica. Druki krakowskie XVI w. Jan Haller (2), „Biuletyn Biblioteki Jagiellońskiej” 1995, t. 45, s. 43-45; idem, Miscellanea bibliographica. Druki krakowskie XVI w. Kasper Hochfeder. Jan Haller. Florian Ungler, „Biuletyn Biblioteki Jagiellońskiej” 1996, t. 46, s. 37-45; idem, Miscellanea bibliographica. Druki krakowskie XVI w. Wolfgang Lern. Jan Haller, „Biuletyn Biblioteki Jagiellońskiej” 1997, t. 47, s. 31-39; idem, Miscellanea bibliographica. Druki krakowskie XVI wieku. Kasper Hochfeder. Jan Haller. Florian Ungler (2), „Biuletyn Biblioteki Jagiellońskiej" 2004, t. 54, s. 69-74; tego wydania nie notuje także: Index 
W trakcie inwentaryzacji zbioru dotychczas nieskatalogowanych fragmentów rękopisów papierowych i starodruków wyciąganych niegdyś z opraw książkowych ${ }^{2}$ natrafiłem na cztery składki formatu in $4^{\circ}-$ pozostałość dwóch egzemplarzy wydania popularnego dziełka Aeliusa Donata Ars Minor, drukowanego u Jana Hallera 24 grudnia 1506 $\mathrm{roku}^{3}$. Składki z pewnością stanowiły wypełnienie oprawy niewielkiego foliantu i zostały wyjęte już po II wojnie światowej, prawdopodobnie przez wieloletniego dyrektora gnieźnieńskiego archiwum, ks. Władysława Zientarskiego.

Pierwszy egzemplarz składa się z 14 kart w dwóch kompletnych składkach $\mathrm{c}^{6}$ i e $\mathrm{e}^{8}$ o sygnaturach: $\mathrm{c}_{\mathrm{i}^{\prime}} \mathrm{c}_{\mathrm{ii}} \mathrm{c}_{\mathrm{iii}},\left[\mathrm{c}_{4}\right],\left[\mathrm{c}_{5}\right],\left[\mathrm{c}_{6}\right]$ oraz $\mathrm{e}_{\mathrm{i}^{\prime}} \mathrm{e}_{\mathrm{ii}^{\prime}} \mathrm{e}_{\mathrm{iii}}$ $\mathrm{e}_{\mathrm{iiii}},\left[\mathrm{e}_{5}\right],\left[\mathrm{e}_{6}\right],\left[\mathrm{e}_{7}\right],\left[\mathrm{e}_{8}\right]$. Z drugiego natomiast zachowało się 10 kart: cała składka c ${ }^{6}$ i wybrakowana e: $k$. $\mathrm{e}_{\mathrm{iii}} \mathrm{e}_{\mathrm{iiii}},\left[\mathrm{e}_{5}\right],\left[\mathrm{e}_{6}\right]$. Karty zadrukowano w jednej kolumnie o rozmiarze $158 \times 107 \mathrm{~mm}$. Tekst wytłoczony został rotundą: hallerowskim pismem $\mathrm{nr}$ 2, tzw. mszalnym większym (stopień $10 \mathrm{ww}=75-76 \mathrm{~mm}$, krój $\left.\mathrm{M}^{18}\right)^{4}$. Na zachowanych w całości stronicach znajduje się 21 wierszy zawierających ok. 30-32 znaki (il. 1, 2). Tekst ozdobiono skromnymi inicjałami: nr 58 (lombardy E, I, L, P, S, U) i 59 (lombard $\mathrm{A})^{5}$ oraz drzeworytem przedstawiającym rozsiekanie św. Stanisława ${ }^{6}$, znajdującym się na k. $\left[\mathrm{e}_{8} \mathrm{r}\right] \mathrm{w}$ pierwszym, kompletniejszym egzemplarzu (k. $\left[\mathrm{e}_{8} \mathrm{v}\right]$ jest niezadrukowana). W tym też obiekcie, na $\mathrm{k}$. $\left[\mathrm{e}_{7} \mathrm{v}\right]$ zachował się kolofon (il. 3) ${ }^{7}$.

Obydwa opisywane fragmenty „Donata” wytłoczono na papierze pochodzącym z papierni w Prądniku Czerwonym, na co wskazują resztki

Aureliensis. Catalogus librorum Sedecimo Saeculo Impressorum. Prima Pars, t. 12, Baden-Baden 2000, s. 330.

${ }^{2} \mathrm{Na}$ zbiór ten zwróciła mi uwage kustosz Archiwum Archidiecezjalnego w Gnieźnie, p. Justyna Mizerka, za co jej w tym miejscu serdecznie dziękuję.

${ }^{3}$ Helena Kapełuś wymienia dwa inne Hallerowskie wydania Ars Minor Donata, przypuszczalnie z 1511 i 1518 roku, por. H. Kapełuś, Jan Haller, w: Polonia Typographica Saeculi Sedecimi, z. 4: Jan Haller. Kraków 1505-1525. Wstęp, wykaz druków, red. A. Kawecka-Gryczowa, Wrocław 1962, s. 50, poz. 88, s. 58, poz. 165; opisywanego wydania nie zna Maria Cytowska, por. M. Cytowska, Od Aleksandra do Alwara (gramatyki tacińskie w Polsce w XVI w.), Wrocław 1968, s. 102.

${ }^{4}$ H. Kapełuś, op.cit., s. 27, tabl. 165.

${ }^{5}$ Ibidem, s. 32.

${ }^{6}$ Ibidem, s. 35, nr 56; ten sam drzeworyt reprodukowany w: K. Piekarski, Kasper Hochfeder. Kraków 1503-1505, w: Polonia Typographica Saeculi Sedecimi, z. 1, Warszawa 1936, s. 51, tabl. 11, drzeworyt 51.

${ }^{7}$ Impreffum Cracouie In edibus II prouidi viri dni Joannis Haller II Anno dni Millefimoquingentefi II mofexto In vigilia natiuitatis xpi. 


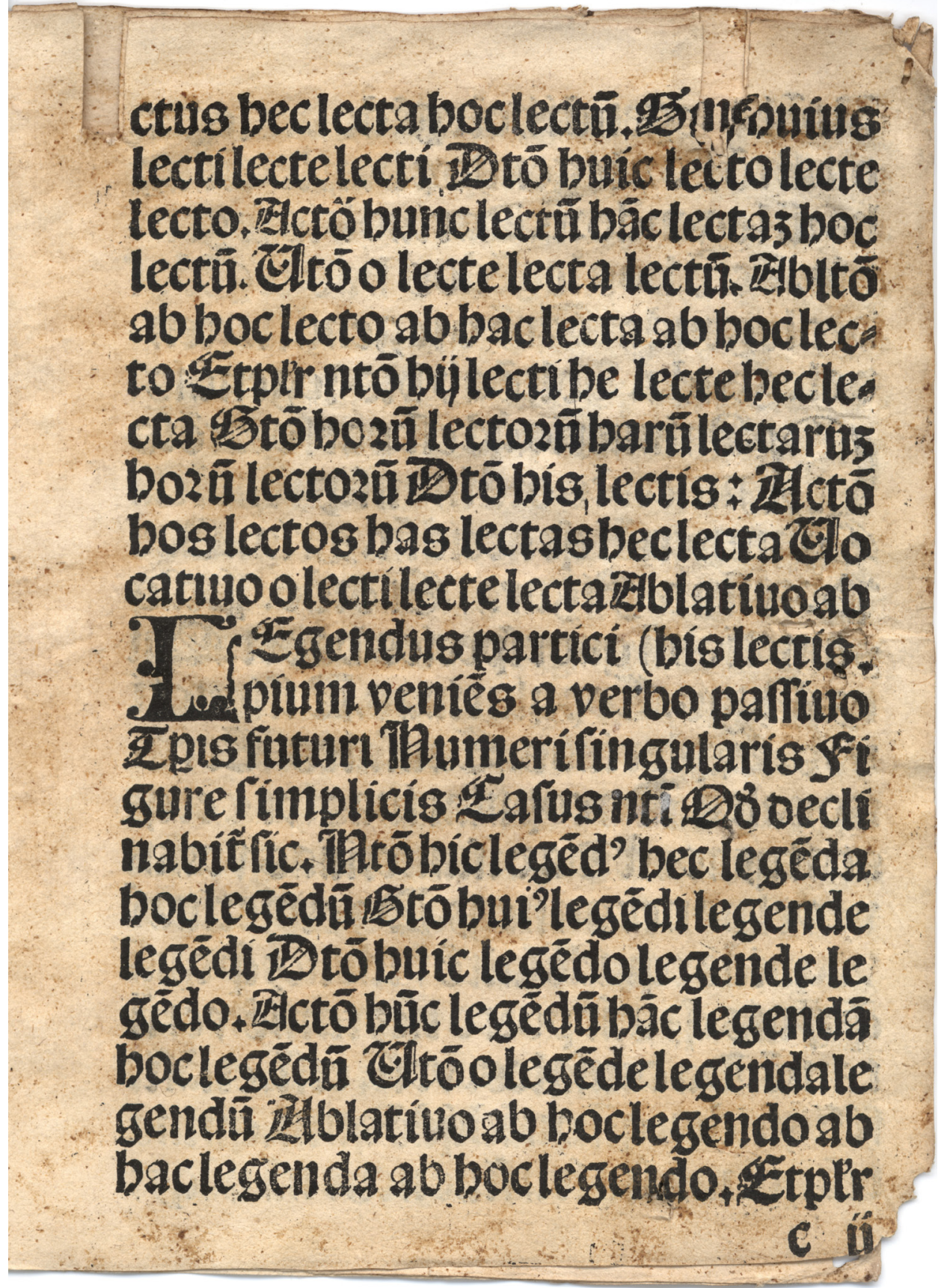

Il. 1. [Aelius Donatus, Ars Minor], Kraków, Jan Haller, 24 XII 1506, 4ㄱ, k. c $\mathrm{c}_{\mathrm{ii}} \mathrm{r}$ Źródło: Archiwum Archidiecezjalne w Gnieźnie, sygn. PL 490. Fot. Tomasz Kawaler. 


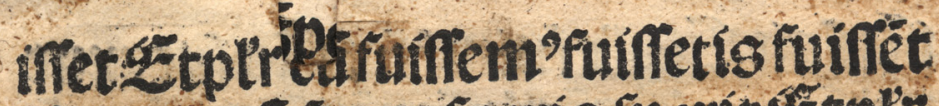
Sanuroci fuerofueris fiterit etplr ciffuerimus fueritisfuerint. Inft. nituo möftuenumerisqufents tpe

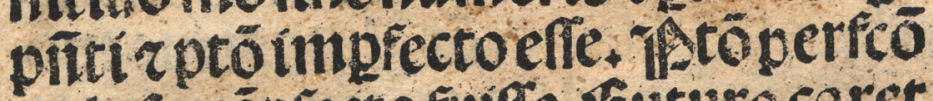
z plufquäpfecto fuiffe. 5 uturo caret

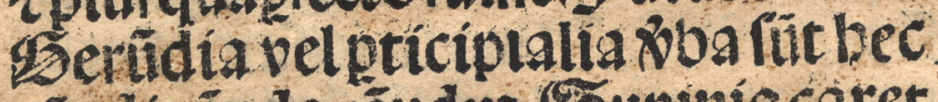

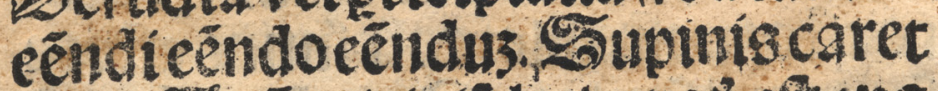
To Elnípticiptí babet qobett ens 2. Coloxbuanomalus in indica. tiuo mó oictĩ tpispîtis numerifín. galaris.figurélímplicis pfonepzie ¿̌́íngatồis icōfequétis qo cōings. biefic Elolo vis vult Etplit volum? vultís vulât Totó ipfécóvolebá vo. lebasvolebat. Etpir volebam?' vole: batts volebàttptó pfccó volut voluí ftivoluit:zplir. boluin' voluiftisto tuerét vel voluere:ptōplufG̈pfctōvo luerä volueras voluerar, Erplitrali ter volueram? volueratis voluerốt

.

Il. 2. [Aelius Donatus, Ars Minor], Kraków, Jan Haller, 24 XII 1506, 4º k. [e $\left.\mathrm{e}_{6} \mathrm{v}\right]$ Źródło: Archiwum Archidiecezjalne w Gnieźnie, sygn. PL 490. Fot. Tomasz Kawaler. 


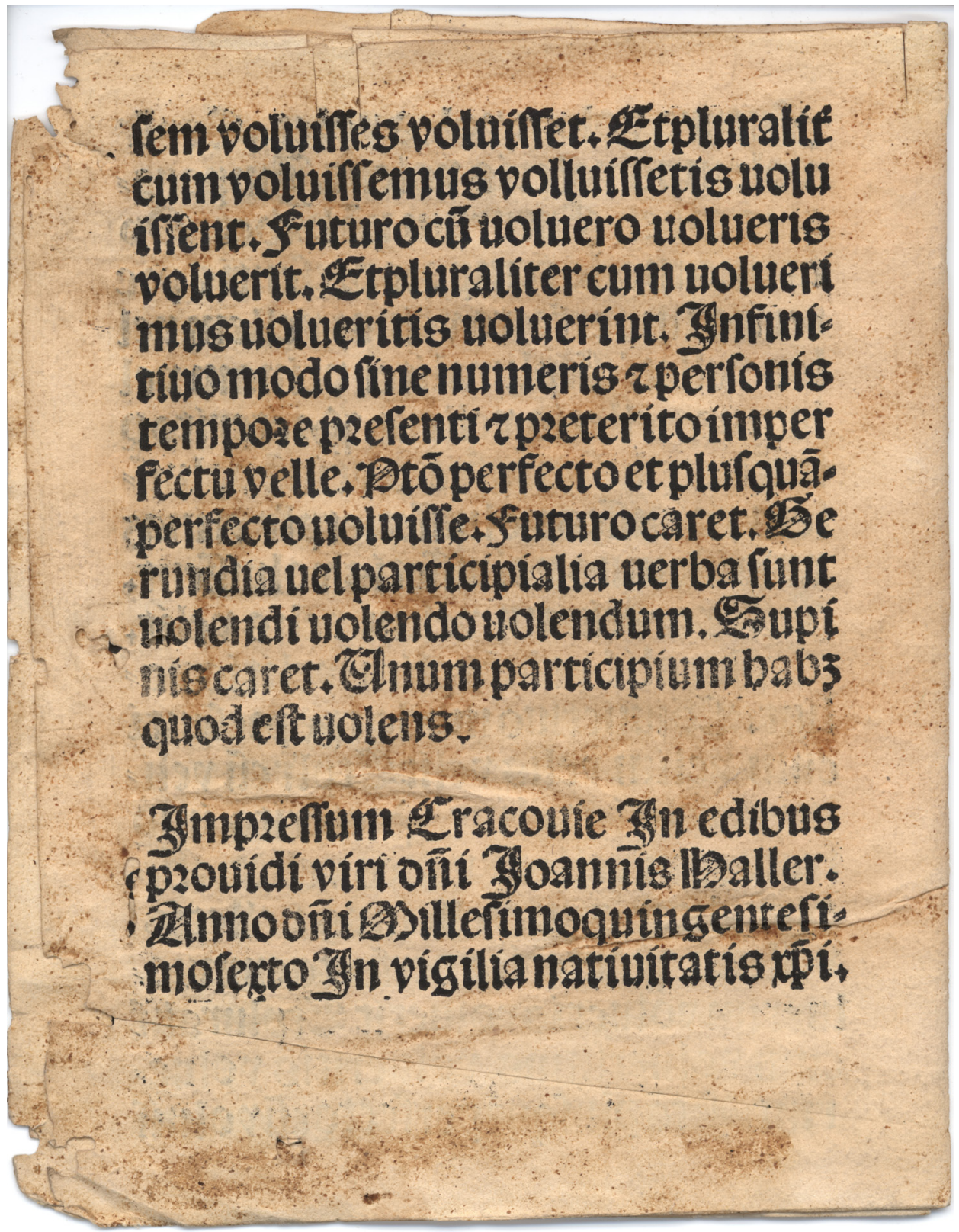

Il. 3. [Aelius Donatus, Ars Minor], Kraków, Jan Haller, 24 XII 1506, 4º k. [e $\left.{ }_{7} \mathrm{v}\right]$, kolofon Źródło: Archiwum Archidiecezjalne w Gnieźnie, sygn. PL 490. Fot. Tomasz Kawaler. 
znaku wodnego, zachowanego na kilku kartach - jest nim charakterystyczny, podwójny krzyż Duchaków ${ }^{8}$.

Pierwotnie druk składał się najpewniej z 34 kart (łącznie z tytułową), w składkach a-e. Warto zauważyć, że niezachowana składka d, po oszacowaniu brakującego tekstu, mogła być złożona z ośmiu kart. Oto proponowany opis odnalezionego zabytku:

[Aelius Donatus, Ars Minor], Kraków, Jan Haller, 24 XII 1506, 4º (k. 34?).

Pismo 2. Inicjały 58, 59. Drzeworyt 56. Egzemplarze: Archiwum Archidiecezjalne Gniezno (AAGn.)., 2 uszkodz. egz. 1.: sygn. PL 490: K. 14: ${ }^{6}$, $\mathrm{e}^{8}$; egz. 2.: sygn. PL 491: K. 10: $\mathrm{c}^{6}, \mathrm{e}_{4}-\mathrm{e}_{6}$.

Na drugi fragment nieznanego Hallerowskiego druku natknąłem się podczas inwentaryzowania późnośredniowiecznej dokumentacji gnieźnieńskiego konsystorza odnalezionej w sierpniu i wrześniu 2015 roku ${ }^{9}$. Z tysięcy strzępów papierowych rękopisów łatwo udało się wydzielić kilkadziesiąt fragmentów wczesnych druków (inkunabułów i druków XVI-wiecznych). Szczególną uwagę zwróciły pozostałości zadrukowanej jednostronnie karty, na której odwrociu naniesiono kilkoma rękami zapiski rękopiśmienne. Resztka karty ma wysokość 217 mm, a w najszerszym zachowanym miejscu $104 \mathrm{~mm}$. Pierwotnie cała miała najpewniej format podłużnego "małego folio", tj. $217 \times 300-320 \mathrm{~mm}^{10}$. Kolumna liczy 18 zachowanych wierszy ${ }^{11}$. Fragmenty pierwszego wydrukowano większym stopniem pisma, pozostałe 17 wierszy mniejszym. Cechy typograficzne wskazuja, że druk niewątpliwie wyszedł z oficyny Jana Hallera. Nagłówek odbito pismem mszalnym większym $\mathrm{nr}$ 2, a tekst główny - pismem nr 4 (rotunda, której wymiary 10 ww. to $56 \mathrm{~mm})(\text { il. } 4)^{12}$.

${ }^{8}$ Najbardziej zbliżone znaki wodne reprodukowane w: W. Budka, Znaki wodne papierni w Rzeczypospolitej Polskiej XVI w., w: Antologia prac historyka papiernictwa Wtodzimierza Budki, red. J. Dąbrowski, Duszniki-Zdrój 2009, s. 257, nr 2 (datowany na 1506 rok); J. Siniarska-Czaplicka, Filigrany papierni położonych na obszarze Rzeczypospolitej Polskiej od początku XVI do połowy XVIII wieku, Wrocław 1969, tabl. 23, nr 115 (datowany na 1507 rok).

9 A. Kozak, J. Łukaszewski, Późnośredniowieczne dokumenty papierowe odnalezione w katedrze gnieźnieńskiej, „Studia Gnesnensia” 2015, t. 29, s. 359-361.

${ }^{10}$ Znak wodny się nie zachował, kresy sita czerpalnego ułożone są poziomo w odstępach o szerokości $31 \mathrm{~mm}, 32 \mathrm{~mm}$.

11 Pierwotny rozmiar kolumny tekstu jest trudny do określenia, wysokość 17 wierszy wytłoczonych mniejszym stopniem pisma to $94 \mathrm{~mm}$.

${ }^{12}$ H. Kapełuś, op.cit., s. 27, tabl. 165, 167. 


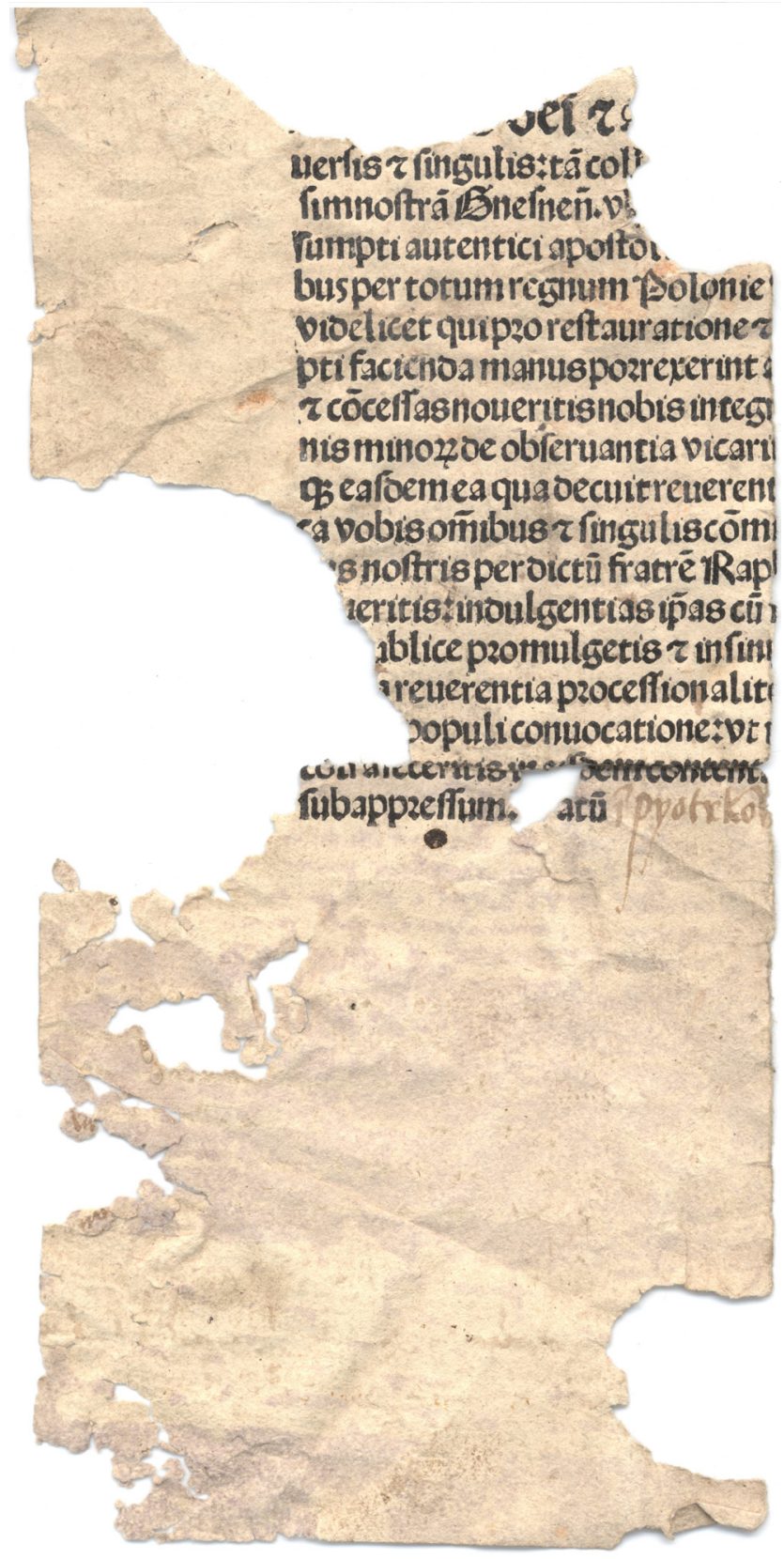

Il. 4. [Mandatum Andreae Archiepiscopi Gnesnensis, Kraków, Jan Haller, ok. 12 III 1509-przed 8 IV 1509], $2^{\circ}$ podł., strona recto

Źródło: Archiwum Archidiecezjalne w Gnieźnie, sygn. PL 492. Fot. Tomasz Kawaler. 
Treść wskazuje, że jest to drukowany formularz dokumentu (mandatu) arcybiskupa gnieźnieńskiego, z okienkiem na wpisanie miejsca i daty wystawienia. Pozostałość nagłówka to element intytulacji arcybiskupiej: dei et a [...]. Całość jednak można zrekonstruować jako dei et a[postolica sedis gracia archiepiscopus Gneznensis], bowiem niżej jest mowa o „naszej diecezji gnieźnieńskiej": [dioece] sim nostra[m] Gnesnen[sem] (3 w.). Pismo adresowane było przez arcybiskupa do kleru jego diecezji (fragment $2 \mathrm{w}$.): universis et singulis $t a[m]$, być może: coll[egiatarum canonicis quam parochialium ecclesiarum rectoribus, vicariis, altaristis]. Natomiast w ostatnim wierszu, po nadrukowanym sformułowaniu: subappressum $[d] a t u[m]$, znajduje się wolne miejsce, w którym odręcznie dopisano: $i[n]$ Pyotrkow $^{13}$. Datowanie druku na podstawie analizy typograficznej w tym przypadku może być niepewne, a dopisana odręcznie data wystawienia zaginęła. Fragmenty treści dokumentu i sześć odręcznych zapisek na jego odwrociu zdradzają który arcybiskup i kiedy wystawił owo pismo, oraz pozwalają datować druk.

Dopiski na stronie dorsalnej nanieśli duchowni (il. 5) ${ }^{14}$. Pierwszy z nich, z powodu uszkodzenia karty, jest niezidentyfikowany, a kolejnymi byli: Jan, wikariusz kościoła parafialnego w Dobrowie; nieznany duchowny z Brudzewa; wikariusz z Janiszewa; Jan, komendarz świątyni parafialnej w Turku oraz Mikołaj, pleban w Russocicach (wszystkie parafie w dawnym dekanacie konińskim $)^{15}$. Kapłani, postępując według ówczesnej praktyki, kolejno poświadczyli pisemnie na odwrociu dokumentu,

${ }^{13}$ Egzemplarz był zapewne uwierzytelniony pieczęcią arcybiskupią (wskazuje na to fragment koroboracji), być może odciśniętą w papierze na podkładzie z wosku, ale zaginęła ona wraz z większą częścią karty.

14 1. [...] ego [Nico?]laus [...] executus sum [...] mandatum [...] processum de[...] [...] $m$ coram Christifidelibus ad divina aud[ienda] congregatis iuxta vim et formam eiusdem; 2. Ipso die Pasce ego Joannes vicarius in Dobrow executus sum presens mandatum quia eundem processum pronunciavi coram Christifidelibus ad divina congregatis iuxta vim [...] remisi ad vicinum proximiorem; 3. Anno quo intra die [...] mensis Aprilis ego [...] in Brudzewo exec[utus sum] [...] eundem processum [...] [Christi]fidelibus ad divina [...] vim et formam [...]; 4. Die Lune IX mensis Aprilis [...] in Janyszewo viccarius presens mandatum [...] eiusdem processum coram Christifidelibus ad divina audienda [...] et eiusdem debito mo[do?] perlegi quem remisi [...] vicinum sine mora; 5. Die Martis X mensis Aprilis ego Johannes comendarius in Thurek $p$ [arens] [mand] atis Reverendissimi domini Andree archiepiscopi Gneznensis [...] executus sum presens mandatum declarando processum coram Christifidelibus ad divina [audi]enda congregatis quem remisi ad alium vicinum sine mora; 6. [Die] Martis X mensis Aprilis ego Nicolaus plebanus in [Russo]czycze parens mandatis Reverendissimi domini [...] archiepiscopi Gneznensis executus sum [...] atum declarando presentem processum [...] coram [Christifide]libus ad divina audienda congregatis [...] remisi ad alium vicinum sine mora.

${ }^{15}$ Joannis de Lasco S.E. Gnesnensis Archiepiscopi, Primatis Legatique Nati Liber Beneficiorum Archidioecesis Gnesnensis, wyd. J. Łukowski, t. 1, Gniezno 1880, s. 251-269. 


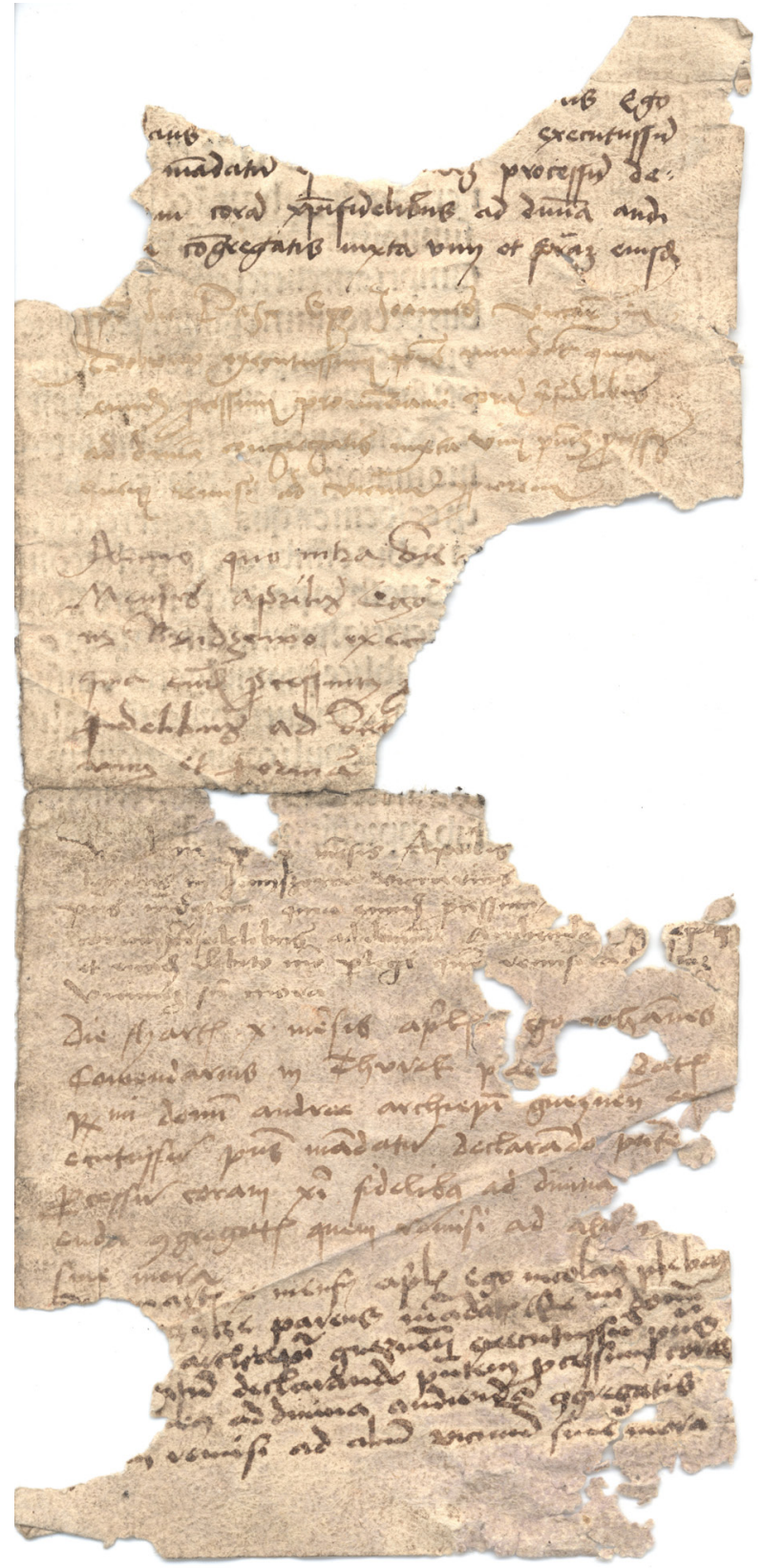

Il. 5. [Mandatum Andreae Archiepiscopi Gnesnensis, Kraków, Jan Haller, ok. 12 III 1509-przed 8 IV 1509], $2^{\circ}$ podł., odwrocie

Źródło: Archiwum Archidiecezjalne w Gnieźnie, sygn. PL 492. Fot. Tomasz Kawaler. 
że wykonali polecenie (mandat) arcybiskupa gnieźnieńskiego Andrzeja, ogłaszające publicznie jego pismo wobec zgromadzonych na modlitwie wiernych, po czym odesłali je bezzwłocznie kolejnym sąsiadom. Szczęśliwie w części not zachowały się zapisane przez duchownych daty dzienne. Dokument ogłoszono w Dobrowie w Wielkanoc (8 kwietnia), w Poniedziałek Wielkanocny pismo powędrowało do Janiszewa, a dzień później (wtorek, 10 kwietnia) trafiło do Turku i Russocic. Taki układ dat w kalendarzu zachodzi kilkakrotnie w XVI wieku, co ważne, także w 1509 roku w czasie gdy arcybiskupem gnieźnieńskim był Andrzej Boryszewski ${ }^{16}$. Opisywany egzemplarz wystawiono w Piotrkowie z pewnością na przełomie marca i kwietnia 1509 roku lub na samym początku kwietnia tegoż roku. Wtedy, od 11 marca do 16 kwietnia, obradował w Piotrkowie sejm walny, w którym uczestniczył też arcybiskup Boryszewski ${ }^{17}$.

Zgodnie z przyjętą praktyką należycie wykonany mandat został dostarczony do Gniezna - przypuszczalnie do urzędu wikariusza generalnego (w tym czasie był nim Wincenty z Łagiewnik, równocześnie oficjał ${ }^{18}$ ), i zapewne dlatego dokument zachował się wśród innych odnalezionych akt konsystorskich.

Sądzę, że treść drukowanego dokumentu arcybiskupiego związana była $\mathrm{z}$ wielkim odpustem jubileuszowym, ogłoszonym przez papieża Juliusza II w bulli z 12 lutego 1507 roku, wysłanej m.in. do Polski 4 listopada 1507 roku. Zebrane w ramach jubileuszu składki w jednej trzeciej miały być przeznaczone na odbudowę bazyliki św. Piotra w Rzymie, a w dwóch trzecich na walkę króla polskiego z niewiernymi; odpust miał trwać dwa lata od momentu publikacji ${ }^{19}$. Zauważę, iż w treści odnalezionego pisma znajduje się kilka charakterystycznych sformułowań często pojawiających się w dokumentach odpustowych, następnie jest mowa o bernardynie Rafale ${ }^{20}$. Skądinąd wiadomo, że władzę głoszenia tego

${ }^{16}$ J. Korytkowski, Arcybiskupi gnieźnieńscy, prymasowie i metropolici polscy od roku 1000 aż do roku 1821, t. 2, Poznań 1888, s. 543-579; A. Knot, Andrzej Boryszewski, w: Polski słownik biograficzny, t. 2, Kraków 1936, s. 359-360.

${ }^{17}$ W. Konopczyński, Chronologia sejmów polskich 1493-1793, Kraków 1948, s. 7; J. Korytkowski, Arcybiskupi..., s. 574, przyp. 3-4.

18 J. Korytkowski, Prataci i kanonicy katedry metropolitalnej gnieźnieńskiej od roku 1000 à do dni naszych, t. 2, Gniezno 1883, s. 493-498.

19 A. Schulte, Die Fugger in Rom 1495-1523: mit Studien zur Geschichte des kirchlichen Finanzwesens jener Zeit, z. 1: Darstellung, Leipzig 1904, s. 55 i n.; K. Kantak, Bernardyni polscy, t. 1: 1453-1572, Lwów 1933, s. 146-147; W. Szymborski, Odpusty w Polsce średniowiecznej, Kraków 2011, s. 542, nr 1460.

${ }^{20}$ W. 6-7: videlicet qui pro restauratione et [...] facienda manus porrexerint; w. 9: [ordi] nis minorum de observantia uicariu[m?]; w. 12: per dictum fratrem Raph[aelem]. 
odpustu jubileuszowego w Polsce uzyskał w 1508 roku Rafał z Proszowic, wikariusz prowincji polskiej bernardynów ${ }^{21}$. W diecezji krakowskiej jubileusz uroczyście ogłoszono 12 marca 1509 roku $^{22}$, a 1 kwietnia tegoż roku na posiedzeniu kapituły katedralnej gnieźnieńskiej ${ }^{23}$. Najpewniej drukowanym u Hallera mandatem arcybiskup Boryszewski polecił duchownym swej diecezji, by poinformowali wiernych o jubileuszu oraz o sposobie korzystania z niego. Dzięki użyciu druku informacja rozeszła się wśród wiernych diecezji gnieźnieńskiej szybko i sprawnie.

Odnaleziony drukowany dokument nie jest jedynym Hallerowskim drukiem o charakterze ulotnym, związanym z jubileuszem 1507 roku. Zwrócę uwagę na unikatowy egzemplarz statutów synodu krakowskiego z 13 lipca 1509 roku $^{24}$ oraz na fragment drukowanego na pergaminie formularza odpustowego (Formulae indulgentiarum) wystawionego przez brata Jana z Komorowa dla bliżej nieznanego Stanisława Wrzesińskiego (druk datowany przez Helenę Kapełuś na rok 1508, przed 8 sierpnia) ${ }^{25}$. Drukowany formularz mandatu arcybiskupa gnieźnieńskiego Andrzeja mógł wyjść z oficyny Hallera zapewne tuż po oficjalnym rozpoczęciu głoszenia jubileuszu w Krakowie, tj. 12 marca 1509 roku (lub krótko przed tą datą), a na pewno przed 8 kwietnia 1509 roku, kiedy odnaleziony w Gnieźnie egzemplarz dotarł do Dobrowa.

Proponuję poniższy opis tego druku:

[Mandatum Andreae Archiepiscopi Gnesnensis, Kraków, Jan Haller, ok. 12 III 1509-przed 8 IV 1509], $2^{\circ}$ podł., k. 1.

K. 1, jednostronnie zadrukowana, formularz z okienkiem, 18 wierszy. Pismo: 2, 4. Egzemplarze: 1.: AAGn., sygn. PL 492, uszkodz.

Z pewnością wydrukowano sporą liczbę egzemplarzy tego mandatu, jednak ze względu na doraźny, ulotny charakter treści szybko uległy one zatraceniu. Szczęśliwie zachowany fragment, wraz z notami o wykonaniu, jest bardzo interesującym przykładem wykorzystania druku

${ }^{21}$ K. Kantak, op.cit., s. 146-147; W. Murawiec, Rafat z Proszowic, w: Polski stownik biograficzny, t. 30, Wrocław 1987, s. 435-436.

${ }^{22}$ K. Kantak, op.cit., s. 146; W. Murawiec, op.cit., s. 435.

${ }^{23}$ J. Korytkowski, Arcybiskupi..., s. 574; Acta Capitulorum nec non Iudiciorum Ecclesiasticorum selecta, t. 1: Acta Capitulorum Gneznensis, Poznaniensis et Vladislaviensis (1408-1530), wyd. B. Ulanowski, Kraków 1894, s. 594, nr 2688.

${ }^{24}$ Biblioteka Jagiellońska, sygn. Cim.Vol. 5, por. J. Sawicki, Concilia Polonie. Źródła i studia krytyczne, t. 1: Statuty synodalne krakowskie biskupa Jana Konarskiego z 1509 r., Lublin 1961, s. 41-42, 51.

${ }^{25}$ Biblioteka Jagiellońska, sygn. Cim.Vol. 13, por. H. Kapełuś, op.cit., s. 23-24, 
u schyłku wieków średnich. Oto ważna informacja ze Stolicy Apostolskiej za pośrednictwem mandatu arcybiskupiego trafiła do kleru parafialnego i wiernych. Zabytek ten i opisane wyżej szczątki nieznanego dotychczas wydania "Donata” uzupełniają wykazy druków pochodzących z Hallerowskiej oficyny.

\section{Bibliografia}

Źródła

Archiwum Archidiecezjalne w Gnieźnie: PL 490, PL 491.

Acta Capitulorum nec non Iudiciorum Ecclesiasticorum selecta, t. 1: Acta Capitulorum Gneznensis, Poznaniensis et Vladislaviensis (1408-1530), wyd. B. Ulanowski, Kraków 1894.

Joannis de Lasco S.E. Gnesnensis Archiepiscopi, Primatis Legatique Nati Liber Beneficiorum Archidioecesis Gnesnensis, wyd. J. Łukowski, t. 1, Gniezno 1880.

\section{Literatura}

Budka W., Znaki wodne papierni w Rzeczypospolitej Polskiej XVI w., w: Antologia prac historyka papiernictwa Włodzimierza Budki, red. J. Dąbrowski, Duszniki-Zdrój 2009.

Bułhak H., Varia Hallerowskie, „Roczniki Biblioteczne” 1985, t. 29, z. 1-2, s. $23-31$. Bułhak H., Miscellanea Bibliographica. Druki krakowskie XVI w. Jan Haller, „Biuletyn Biblioteki Jagiellońskiej" 1991, t. 41, s. 73-80.

Bułhak H., Miscellanea bibliographica. Druki krakowskie XVI w. Jan Haller (2), „Biuletyn Biblioteki Jagiellońskiej" 1995, t. 45, s. 43-45.

Bułhak H., Miscellanea bibliographica. Druki krakowskie XVI w. Kasper Hochfeder. Jan Haller. Florian Ungler, „Biuletyn Biblioteki Jagiellońskiej” 1996, t. 46, s. 37-45.

Bułhak H., Miscellanea bibliographica. Druki krakowskie XVI wieku. Kasper Hochfeder. Jan Haller. Florian Ungler (2), „Biuletyn Biblioteki Jagiellońskiej” 2004, t. 54, s. 69-74.

Bułhak H., Miscellanea bibliographica. Druki krakowskie XVI w. Wolfgang Lern. Jan Haller, „Biuletyn Biblioteki Jagiellońskiej” 1997, t. 47, s. 31-39.

Cytowska M., Od Aleksandra do Alwara (gramatyki tacińskie w Polsce w XVI w.), Wrocław 1968.

Index Aureliensis. Catalogus librorum Sedecimo Saeculo Impressorum. Prima Pars, t. 12, Baden-Baden 2000, s. 330 .

Kantak K., Bernardyni polscy, t. 1: 1453-1572, Lwów 1933.

Kapełuś H., Jan Haller, w: Polonia Typographica Saeculi Sedecimi, z. 4: Jan Haller. Kraków 1505-1525. Wstęp. Wykaz druków, Wrocław 1962.

Kawecka-Gryczowa A., Jan Haller, w: Drukarze dawnej Polski od XV do XVIII wieku, t. 1: Małopolska, cz. 1: Wiek XV-XVI, red. A. Kawecka-Gryczowa, Wrocław 1982. 
Knot A., Andrzej Boryszewski, w: Polski słownik biograficzny, t. 2, Kraków 1936.

Konopczyński W., Chronologia sejmów polskich 1493-1793, Kraków 1948.

Korytkowski J., Prałaci i kanonicy katedry metropolitalnej gnieźnieńskiej od roku 1000 aż do dni naszych, t. 2, Gniezno 1883.

Korytkowski J., Arcybiskupi gnieźnieńscy, prymasowie i metropolici polscy od roku 1000 aż do roku 1821, t. 2, Poznań 1888.

Kozak A., Łukaszewski J., Późnośredniowieczne dokumenty papierowe odnalezione w katedrze gnieźnieńskiej, „Studia Gnesnensia” 2015, t. 29, s. 359-361.

Murawiec W., Rafał z Proszowic, w: Polski słownik biograficzny, t. 30, Wrocław 1987.

Piekarski K., Kasper Hochfeder. Kraków 1503-1505, w: Polonia Typographica Saeculi Sedecimi, z. 1, Warszawa 1936.

Sawicki J., Concilia Polonie. Źródła i studia krytyczne, t. 1: Statuty synodalne krakowskie biskupa Jana Konarskiego z 1509 r., Lublin 1961.

Schulte A., Die Fugger in Rom 1495-1523: mit Studien zur Geschichte des kirchlichen Finanzwesens jener Zeit, z. 1: Darstellung, Leipzig 1904.

Siniarska-Czaplicka J., Filigrany papierni położonych na obszarze Rzeczypospolitej Polskiej od poczatku XVI do połowy XVIII wieku, Wrocław 1969.

Szymborski W., Odpusty w Polsce średniowiecznej, Kraków 2011.

\title{
JAKUB ŁUKASZEWSKI
}

\section{Fragments of two unknown prints from Jan Haller printing office (from 1506 and 1509)}

\begin{abstract}
Aвstract. The communique describes the fragments of two unknown prints from the printing office of Jan Haller that have been found in the Archdiocese Archives in Gniezno. These are the remnants of two copies of the Ars Minor by Aelius Donat (published Dec. 24, 1506) and a printed form of the mandate for Archbishop Andrzej Boryszewski (issued approximately on March 12, 1509, but before Apr. 08, 1509).
\end{abstract}

Key words: Jan Haller, Donatus, Ars Minor, Andrzej Boryszewski, old prints, typography, Archdiocese Archives in Gniezno. 
